\title{
Milk somatic cell count, lactate dehydrogenase activity, and immunoglobulin G concentration associated with mastitis caused by different pathogens: a field study
}

\author{
Hernández-Castellano, L E ; Wall, S K ; Stephan, Roger ; Corti, Sabrina ; Bruckmaier, Rupert M
}

\begin{abstract}
The aim of this study is to analyze how somatic cell counts (SCC), immunoglobulin G (IgG), and lactate dehydrogenase $(\mathrm{LDH})$ interact dependent on the mastitis causing pathogen. Milk samples from 152 quarters were collected on 2 Swiss dairy farms equipped with automatic milking systems. Bacteriological culturing was performed and SCC, LDH activity and IgG concentrations were measured in each sample. Correlations and regressions among SCC, LHD, and IgG were calculated after grouping by the pathogen type (control, S. aureus, C. bovis, coagulase-negative Staphylococcus and S. uberis). All the mastitis causing pathogens were gram-positive bacteria (except for 3 cases with E. coli). In this study, the SCC and LDH were affected by the pathogen group. However, only in the S. uberis group the IgG concentration was higher than in the controls. All studied variables were positively correlated among each other. SCC and LDH were the highest correlated parameters in the control, S. aureus, C. bovis and coagulase- negative Staphylococcus groups. Only in the S. uberis group the correlation between LDH and IgG was higher than the correlation between SCC and LDH. The regression coefficients for SCC and $\mathrm{LDH}$ differed between groups whereas regression coefficients for SCC and IgG, and for LDH and IgG were similar in all groups. Because cases with E. coli infection were so rare, we could not include these cases in the statistical evaluation. Based on these few cases E. coli $(n=3)$ seemed to cause a much higher increase of IgG and LDH than the infection with gram-positive bacteria. This study shows that the suitability of LDH as a marker for IgG transfer is dependent on the pathogen. The use of LDH in combination with SCC may be used as a marker to differentiate between gram-positive and gram-negative bacteria, but does not allow differentiating the immune response between different gram-positive bacteria.
\end{abstract}

DOI: https://doi.org/10.17236/sat00115

Other titles: Somatische Zellzahl, Laktatdehydrogenase, und Immunglobulin G in der Milch bei Mastitiden, die durch verschiedene Pathogene verursacht wurden: eine Feldstudie

Posted at the Zurich Open Repository and Archive, University of Zurich

ZORA URL: https://doi.org/10.5167/uzh-148869

Journal Article

Published Version

Originally published at:

Hernández-Castellano, L E; Wall, S K; Stephan, Roger; Corti, Sabrina; Bruckmaier, Rupert M (2017). Milk somatic cell count, lactate dehydrogenase activity, and immunoglobulin G concentration associated with mastitis caused by different pathogens: a field study. Schweizer Archiv für Tierheilkunde, 159(5):283290.

DOI: https://doi.org/10.17236/sat00115 


\title{
Milk somatic cell count, lactate dehydro- genase activity, and immunoglobulin $\mathrm{G}$ concentration associated with mastitis caused by different pathogens: A field study
}

\author{
L.E. Hernández-Castellano', S. K. Wall'1, R. Stephan², S. Corti², R. M. Bruckmaier ${ }^{1}$ \\ ${ }^{1}$ Veterinary Physiology, Vetsuisse Faculty University of Bern, ${ }^{2}$ Institute for Food Safety and Hygiene, \\ Vetsuisse Faculty University of Zurich, Switzerland
}

\begin{abstract}
The aim of this study is to analyze how somatic cell counts (SCC), immunoglobulin $\mathrm{G}(\mathrm{IgG})$, and lactate dehydrogenase (LDH) interact dependent on the mastitis causing pathogen. Milk samples from 152 quarters were collected on 2 Swiss dairy farms equipped with automatic milking systems. Bacteriological culturing was performed and SCC, LDH activity and IgG concentrations were measured in each sample. Correlations and regressions among SCC, LHD, and IgG were calculated after grouping by the pathogen type (control, S. aureus, C. bovis, coagulase-negative Staphylococcus and S. uberis). All the mastitis causing pathogens were gram-positive bacteria (except for 3 cases with E. coli). In this study, the SCC and LDH were affected by the pathogen group. However, only in the S. uberis group the $\operatorname{IgG}$ concentration was higher than in the controls. All studied variables were positively correlated among each other. SCC and LDH were the highest correlated parameters in the control, S. aureus, C. bovis and coagulase-negative Staphylococcus groups. Only in the $S$. $u b$ eris group the correlation between $\mathrm{LDH}$ and $\mathrm{IgG}$ was higher than the correlation between SCC and LDH. The regression coefficients for SCC and LDH differed between groups whereas regression coefficients for SCC and $\mathrm{IgG}$, and for LDH and $\operatorname{IgG}$ were similar in all groups. Because cases with E. coli infection were so rare, we could not include these cases in the statistical evaluation. Based on these few cases E. $\operatorname{coli}(\mathrm{n}=3)$ seemed to cause a much higher increase of $\operatorname{IgG}$ and LDH than the infection with gram-positive bacteria. This study shows that the suitability of $\mathrm{LDH}$ as a marker for $\mathrm{IgG}$ transfer is dependent on the pathogen. The use of LDH in combination with SCC may be used as a marker to differentiate between gram-positive and gram-negative bacte-
\end{abstract}

Somatische Zellzahl, Laktatdehydrogenase, und Immunglobulin G in der Milch bei Mastitiden, die durch verschiedene Pathogene verursacht wurden: Eine Feldstudie

In der aktuellen Studie wurden die Zusammenhänge zwischen somatischer Zellzahl (SCC), Immunglobulin $\mathrm{G}(\mathrm{IgG})$ und Laktatdehydrogenase (LDH) in Abhängigkeit vom Mastitis-auslösenden Pathogen untersucht. Milchproben von 152 Eutervierteln wurden auf zwei Schweizer Melkroboter-Betrieben entnommen. Neben der Bestimmung von SCC, IgG, und LDH wurden die Proben bakteriologisch untersucht. Nach der Einteilung in Pathogen-Typen (Kontrollen, S. aureus, C. bovis, Coagulase-negative Staphylokokken, S. uberis) wurden Korrelationen und Regressionen zwischen SCC, LDH und IgG berechnet. Alle gefundenen Mastitis-Pathogene waren gram-positive Bakterien; lediglich 3 Viertel waren mit E. coli infiziert. Sowohl SCC wie auch LDH unterschieden sich zwischen den Pathogen-Typen. Aber nur in Vierteln, in denen S. uberis nachgewiesen wurde, war IgG gegenüber den Kontrollen erhöht. Alle untersuchten Variablen waren untereinander positiv korreliert. Für Kontrollen, S. aureus, C. bovis, Coagulase-negative Staphylokokken waren SCC und LDH am höchsten miteinander korreliert. Nur in der S. uberis Gruppe war die Korrelation zwischen LDH und IgG höher als die zwischen SCC und LDH. Die Regressionskoeffizienten zwischen SCC und LDH unterschieden sich zwischen den Pathogen-Typen, während die Regressionen zwischen SCC und IgG sowie zwischen LDH und IgG keine Gruppenunterschiede zeigten. Aufgrund ihrer geringen Zahl $(\mathrm{n}=3)$ konnten die mit E. coli infizierten Viertel nicht in die statistische Auswertung einbezogen https://doi.org/ $10.17236 /$ sat00115

Received: 02.07.2016 Accepted: 15.09.2016 
Milk somatic cell count, lactate dehydrogenase activity, and immunoglobulin $\mathrm{G}$ concentration associated with mastitis caused by different pathogens: A field study

L.E. Hernández-Castellano ria, but does not allow differentiating the immune response between different gram-positive bacteria.

Keywords: mastitis, somatic cell counts, immunoglobulin G, lactate dehydrogenase werden. Tatsache ist aber, dass bei allen E. coli Vierteln für IgG und LDH viel höhere Werte gemessen wurden als bei allen mit gram-positiv infizierten Vierteln. Diese Studie zeigt, dass die Brauchbarkeit von LDH als Marker für den Transfer von IgG vom Blut in die Milch pathogen-abhängig ist. Die Beziehung zwischen SCC und LDH könnte als Marker dienen für die Unterscheidung von gram-positiven und gram-negativen Infektionen wohingegen eine Unterscheidung zwischen verschiedenen gram-positiven Bakterien nicht möglich erscheint.

Schlüsselwörter: Mastitis, Somatische Zellzahl, Immunglobulin G, Laktatdehydrogenase

\section{Introduction}

Intramammary infection in dairy cows impacts animal welfare and contributes to economic losses for farmers (Halasa et al., 2007). Importantly, early detection of mastitis and characterization of the pathogen is essential to allow for the separation of milk from infected animals and to optimize treatments to improve the recovery rate and minimize economic losses (Milner et al., 1997; Lehmann et al., 2015). Currently, the most sensitive technique available for clinical and subclinical mastitis detection is the somatic cell counts (SCC) measurement, while the identification of pathogens requires bacteriological culturing or PCR (Nyman et al., 2014). In addition to the innate immune response, represented by increasing SCC, immunoglobulins (mainly $\mathrm{IgG}$ ) are important components of the specific immune response transferred from blood to milk during mastitis. The increase of IgG in milk appears to be pathogen-dependent. In experiments performed using cell wall components from gram-negative and gram-positive bacteria, an increase of $\operatorname{IgG}$ was mainly observed in response to gram-negative but not gram-positive bacteria (Wellnitz et al., 2013). Thus, the transfer of $\operatorname{IgG}$ from blood to milk seems to be an important indicator for the bacterial type that is present in the udder and also the expected course of the disease. This knowledge can provide insight about treatments for individual mastitis cases and aid in prudent use of antibiotics. However, IgG measurement is complex and not readily available for farmers. Therefore, easy measurable parameters representing the transfer of IgG into milk are needed. Lactate dehydrogenase (LDH) activity has also been considered recently as an indicator of the udder health (Chagunda et al., 2006; Hiss et al., 2007), increasing during mammary gland infections. Consequently, milk LDH activity has been considered a suitable marker for the presence of $\operatorname{IgG}$ in milk (Lehmann et al., 2013). Recent publications indicate that most of the $\mathrm{LDH}$, together with other components such as IgG, SCC or $\beta$-hydroxybutyric acid (BHBA), is transferred through the blood- milk barrier as a consequence of reduced integrity during mastitis (Wellnitz et al., 2011; Lehmann et al., 2013). Therefore, the aim of this study was to test the hypothesis that the correlation and regression between the variables SCC, $\mathrm{LDH}$ activity, and $\mathrm{IgG}$ concentration in milk from infected quarters differ depending on the pathogens causing the infection.

\section{Material and Methods}

\section{Collection and processing of milk samples}

Quarter milk samples $(n=152)$ were collected from 38 Brown Swiss dairy cows on two dairy farms in Switzerland equipped with automatic milking systems. Two visits for sampling collection were performed on each farm. Cows with SCC $>100,000$ cells $/ \mathrm{mL}$ in composite milk were selected for sample collection. Following a brief udder cleaning, two streams of foremilk were removed prior to sample collection. Quarter milk samples $(5 \mathrm{~mL})$ were collected first for the analyses of SCC, LDH activity and IgG concentration. Next, sterile quarter milk samples $(12 \mathrm{~mL})$ were collected after sanitization of the quarter following standard recommendations by Hogan et al. (1999). All samples were immediately refrigerated after collection $\left(4^{\circ} \mathrm{C}\right)$ and then placed on ice for transportation from the farm.

This study did not involve any capture of live animals or animal experimentation, thus no specific ethical approval was necessary.

\section{Bacteriological culturing}

Immediately after arrival at the laboratory, the milk samples were taken for bacteriological testing. Using a sterile loop, milk samples $(10 \mu l)$ were streaked on sheep blood agar base (Beckton Dickinson AG, Allschwil, Switzerland), supplemented with $5 \%$ sheep blood (Oxoid, Pratteln, Switzerland) as well as on BROLACIN-Agar (VWR International AG, Dietikon, Switzerland). Samples were incubated at $37^{\circ} \mathrm{C}$ overnight. 
Bacterial colonies were subjected to gram staining and then identification was performed according to accepted standards based on phenotypical and biochemical tests (Anonymous, 1999). Samples with no bacteria growing were used for setting the control group.

\section{SCC, LDH activity and IgG concentration analysis}

SCC in quarter milk samples $(5 \mathrm{~mL})$ was determined using a DeLaval cell counter (DeLaval, Tumba, Sweden) according to the manufacturer's protocol. Only in cases were the cell count was $>3 \times 10^{6}$ cells $/ \mathrm{mL}$ the samples were diluted 1:10 in commercially available milk because the detection limit for the cell counter is between $3 \times 10^{6}$ and $4 \times 10^{6}$ cells $/ \mathrm{mL}$. After measurement, samples were frozen at $-20^{\circ} \mathrm{C}$ for further analyses.

LDH activity and $\operatorname{IgG}$ concentration were measured in milk serum prepared by a two-step centrifugation at $4000 \times g$ for $15 \mathrm{~min}$ at $4 \mathrm{oC}$ and at $14000 \times g$ for $30 \mathrm{~min}$ at $4{ }^{\circ} \mathrm{C}$. A commercial test kit LDH IFCC (Axon Lab AG, Baden, Switzerland) was used for LDH activity and measurements were performed by an automated analyzer (COBAS MIRA, Roche Diagnostics, Basel, Switzerland). Minimum detectable activity was $5 \mathrm{U} / \mathrm{L}$.

Total IgG concentration was measured using a commercial ELISA kit, specific for bovine IgG, (Bethyl Laboratories, Montgomery TX, USA) with the following modifications as described by Lehmann et al. (2015). Briefly, samples were blocked in 5\% fish skin gelatin (Sigma-Aldrich, St. Louis MO, USA) diluted in double distilled water. Samples were diluted in wash buffer (50 $\mathrm{m} M$-Tris, $0.14 M \mathrm{NaCl}, 0.05 \%$ Tween 20 , adjusted to $\mathrm{pH} 8.0$ ) to ensure the samples were within the range of the standard curve. The standard curve was adjusted to 400, 300, 150, 75, 37.5, 18.75, and $9.375 \mathrm{ng} / \mathrm{mL}$. Absorbance measurements were read on the Synergy Mx plate reader (Bio Tec Instruments, Winooski VT, USA). The inter- and intra- assay coefficients of variation were $\sim 3$ and $\sim 8 \%$, respectively. The minimum detectable concentration was $9.375 \mathrm{ng} / \mathrm{mL}$ and samples were performed in duplicate.

\section{Statistical Analysis}

The ANOVA procedure of SAS (Version 9.4, SAS Institute, Cary, NC) was used to evaluate the effect of bac- teriology (fixed effect) on the dependent variables SCC, LDH activity and IgG concentration. The CORR and GLM procedures of SAS were performed on SCC, LDH activity and $\mathrm{IgG}$ concentration for every bacterial group. Results were considered statistically significant when $P<0.05$. Data of SCC and LDH activity were $\log 10$ transformed before statistical analysis to ensure normal distribution. All quarter samples were considered independently of each other in the statistical analysis, as milk produced in one gland is not expected to affect the other quarters (Wellnitz et al., 2011; Wellnitz et al., 2013; Wall et al., 2016). The E. coli group was not considered for any statistical evaluation due to the low number of detected cases $(n=3)$.

\section{Results}

\section{Bacterial groups detected in milk samples}

In $129(84.9 \%)$ of 152 quarter milk samples udder pathogens were detected. According to the bacteriological culturing, 126 samples were obtained from quarters infected with gram-positive pathogens $(97.7 \%$ of bacteriological positive quarters) and 3 samples from quarters with gram-negative pathogens $(2.3 \%$ of bacteriological positive quarters). In detail and according to the bacterial species isolated, samples were grouped in control (23 samples), S. aureus (43 samples, 33.3\% of bacteriological positive quarters), C. bovis (34 samples, $26.3 \%$ of bacteriological positive quarters), coagulase-negative Staphylococcus (35 samples, 27.1\% of bacteriological positive quarters) and S. uberis (14 samples, $10.9 \%$ of bacteriological positive quarters). E. coli was detected in three samples ( $2.3 \%$ of bacteriological positive quarters).

\section{SCC, LDH activity, and IgG concentration in milk from infected and non-infected quarters}

The SCC, LDH activity, and IgG concentration of the quarter milk samples are summarized in Table 1. These results showed that SCC was increased in all bacteriological positive quarters compared to the control ones (4.6 $\log 10 \mathrm{SCC} / \mathrm{mL})$. However, no differences in SCC were observed when different pathogens were compared. Similarly, control quarters had lower LDH activity than quarters from which $S$. aureus, S. uberis and coagulase-negative Staphylococcus (CNS) were isolated, but no
Milk somatic cell count, lactate dehydrogenase activity, and immunoglobulin $\mathrm{G}$ concentration associated with mastitis caused by different pathogens: A field study

L.E. Hernández-Castellano et al.

Table 1: SCC, LDH and IgG concentrations in quarter milk samples with and without isolation of udder pathogens. ${ }^{\mathrm{a}-\mathrm{c}} \mathrm{Means}$ within a raw with different superscripts differ significantly $(\mathrm{P}<0.05) .{ }^{\dagger}$ No pathogen isolated. ${ }^{\ddagger}$ Not statistically tested. ${ }^{\S}$ CNS: Coagulase-negative Staphylococcus.

\begin{tabular}{|c|c|c|c|c|c|c|}
\hline & Control $^{\dagger}(n=23)$ & E. $\operatorname{coli}^{\ddagger}(\mathrm{n}=3)$ & C. bovis $(\mathrm{n}=34)$ & $\mathrm{CNS}^{\S}(\mathrm{n}=35)$ & S. aureus $(n=43)$ & S. uberis $(n=14)$ \\
\hline $\mathrm{SCC}(\log 10 \mathrm{SC} / \mathrm{mL})$ & $4.6 \pm 0.08^{a}$ & $6.34 \pm 0.33^{*}$ & $5.63 \pm 0.10^{b}$ & $5.56 \pm 0.12^{b}$ & $5.35 \pm 0.09^{b}$ & $5.77 \pm 0.20^{b}$ \\
\hline LDH $(\log 10 \mathrm{U} / \mathrm{L})$ & $1.77 \pm 0.30^{a}$ & $2.68 \pm 0.29^{*}$ & $2.07 \pm 0.47^{\mathrm{ab}}$ & $2.19 \pm 0.44^{b}$ & $2.14 \pm 0.42^{b}$ & $2.81 \pm 0.76^{c}$ \\
\hline $\operatorname{lgG}(\mathrm{mg} / \mathrm{mL})$ & $0.22 \pm 0.02^{\mathrm{a}}$ & $1.35 \pm 0.43^{*}$ & $0.53 \pm 0.08^{\mathrm{ab}}$ & $0.51 \pm 0.09^{\mathrm{ab}}$ & $0.46 \pm 0.07^{\mathrm{ab}}$ & $0.79 \pm 0.19^{b}$ \\
\hline
\end{tabular}


Milk somatic cell count, lactate dehydrogenase activity, and immunoglobulin $\mathrm{G}$ concentration associated with mastitis caused by different pathogens: A field study

L.E. Hernández-Castellano et al. difference was detected between controls and quarters from which C. bovis was isolated. The highest LDH activity $(2.81 \log 10 \mathrm{U} / \mathrm{L})$ was recorded in quarters from which S. uberis was found. As described above, the E. coli group was not tested for any statistical evaluation, however according to the values showed in Table 1, it could be speculated that quarters with isolation of $E$. coli should have high SCC (6.34 $\log 10 \mathrm{SCC} / \mathrm{mL})$ and LDH activity $(2.68 \log 10 \mathrm{U} / \mathrm{L})$.

Lower IgG concentration was found in control quarters $(0.22 \mathrm{mg} / \mathrm{mL})$ compared to quarters with $S$. uberis $(0.79$ $\mathrm{mg} / \mathrm{mL})$. No differences in the total IgG concentration were observed for the other bacterial species compared to control quarters. Similarly, according to the E. coli cases detected in the present study, it appears that $\operatorname{IgG}$ concentration is increased in quarters infected with this gram-negative bacteria $(1.35 \mathrm{mg} / \mathrm{mL})$.
Correlations and regressions between SCC, LDH activity and IgG in quarter milk samples

Results obtained from SCC, LDH activity and IgG measurements were used to calculate correlations (Tab. 2) as well as differences among different pathogen regressions between the three variables (Tab. 3, 4 and 5). When samples were examined independently of the isolated udder pathogen, higher correlation was obtained between LDH activity and SCC $(r=0.73)$ than either LDH activity and IgG concentration $(r=0.52)$ or SCC and $\mathrm{IgG}$ concentration $(r=0.42)$. After quarter milk samples were classified by the isolated udder pathogen (control, S. aureus, C. bovis, CNS and S. uberis), different correlations and regression patterns were observed. Both control and infected milk samples showed positive correlation between LDH activity and SCC, with the exception of those from which $S$. uberis was isolated. The highest correlation between LDH activity and SCC was observed for milk samples from which C. bovis $(\mathrm{r}=0.84)$ was isolated, followed by $S$. aureus $(\mathrm{r}=$

Table 2: Correlation, between logLDH, logSCC and IgG in milk samples from which different udder pathogens were isolated. ${ }^{\dagger}$ No pathogen isolated. ${ }^{\ddagger}$ Not statistically tested. ${ }^{\S}$ CNS: Coagulase-negative Staphylococcus.

\begin{tabular}{|c|c|c|c|c|}
\hline & & $\log \mathrm{LDH} / \log \mathrm{SCC}$ & $\operatorname{logSCC} / \lg G$ & $\log \mathrm{LDH} / \lg \mathrm{G}$ \\
\hline \multirow{4}{*}{ Control $^{\dagger}$} & Correlation & 0.73 & 0.04 & -0.23 \\
\hline & a & 0.50 & 0.06 & 1.68 \\
\hline & $\mathrm{b}$ & 0.28 & 0.04 & 0.27 \\
\hline & $p$-value & 0.0001 & 0.8517 & 0.2828 \\
\hline \multirow{4}{*}{ E. coli ${ }^{\ddagger}$} & Correlation & - & - & - \\
\hline & a & - & - & - \\
\hline & $\mathrm{b}$ & - & - & - \\
\hline & $\mathrm{p}$-value & - & - & - \\
\hline \multirow{4}{*}{ C. bovis } & Correlation & 0.84 & 0.49 & 0.51 \\
\hline & $\mathrm{a}$ & -1.05 & -0.97 & 1.78 \\
\hline & $\mathrm{b}$ & 0.58 & 0.26 & 0.66 \\
\hline & $\mathrm{p}$-value & 0.0001 & 0.0156 & 0.0101 \\
\hline \multirow{4}{*}{$\mathrm{CNS}^{\S}$} & Correlation & 0.58 & 0.33 & 0.48 \\
\hline & a & -0.41 & -0.50 & 1.97 \\
\hline & $\mathrm{b}$ & 0.58 & 0.16 & 0.42 \\
\hline & $\mathrm{p}$-value & 0.0011 & 0.0452 & 0.0098 \\
\hline \multirow{4}{*}{ S. aureus } & Correlation & 0.81 & 0.30 & 0.32 \\
\hline & $\mathrm{a}$ & -2.06 & -0.54 & 1.90 \\
\hline & $\mathrm{b}$ & 0.73 & 0.17 & 0.58 \\
\hline & $\mathrm{p}$-value & 0.0001 & 0.05 & 0.0373 \\
\hline \multirow{4}{*}{ S. uberis } & Correlation & 0.53 & 0.60 & 0.76 \\
\hline & $a$ & -0.48 & -1.59 & 1.91 \\
\hline & $\mathrm{b}$ & 0.47 & 0.41 & 0.88 \\
\hline & $\mathrm{p}$-value & 0.27 & 0.21 & 0.0413 \\
\hline \multirow{4}{*}{ Total } & Correlation & 0.73 & 0.42 & 0.52 \\
\hline & a & -0.49 & -0.61 & 1.79 \\
\hline & $\mathrm{b}$ & 0.47 & 0.18 & 0.70 \\
\hline & $p$-value & 0.0001 & 0.0001 & 0.0001 \\
\hline
\end{tabular}


$0.81)$, control $(\mathrm{r}=0.73)$ and coagulase-negative Staphylococcus $(\mathrm{r}=0.58)$.

When examining the LDH activity and SCC regression slopes by bacteria, differences between $C$. bovis and coagulase-negative Staphylococcus, control and CNS, and C. bovis and S. uberis regression slopes were observed. Regardless of these results, no differences were found between other regression slopes. There was no significant correlation between SCC and IgG concentration observed for control quarters. Additionally, only quarter milk samples from which C. bovis, CNS and S. aureus were isolated showed a significant correlation between SCC and IgG concentration, although these parameters were not highly correlated in these groups $(r=0.49$, $r=0.33$ and $r=0.30$, respectively).

Also, there was no significant correlation found in control milk samples between LDH activity and IgG concentration. Milk samples with $C$. bovis, coagulase-negative Staphylococcus, S. aureus and S. uberis had a significant correlation. Overall, the highest correlations between
LDH activity and $\operatorname{IgG}$ concentration were obtained when S. uberis or C. bovis ( $\mathrm{r}=0.76$ and $\mathrm{r}=0.51$, respectively) were isolated from milk samples. No differences were detected between groups either for SCC/IgG or $\mathrm{LDH}$ activity/IgG concentration regression slopes. As a consequence of the low number of quarter milk samples from which gram-negative bacteria $(E$. coli, $\mathrm{n}=3)$ were isolated, this group could not be tested for any correlation or regression. However, based on the few individual cases, E. coli infections seem to be represented by much higher LDH activity at a given SCC level than all cases with gram-positive infections.

\section{Discussion}

In the present study, quarter milk samples from which $S$. aureus, S. uberis and coagulase-negative Staphylococcus were isolated had higher LDH activity than milk samples from control quarters, but this did not occur in milk samples with $C$. bovis. Specifically, the highest LDH activity was recorded in samples from which S. uberis $(2.81 \log 10 \mathrm{U} / \mathrm{L})$
Milk somatic cell count, lactate dehydrogenase activity, and immunoglobulin $\mathrm{G}$ concentration associated with mastitis caused by different pathogens: A field study

L.E. Hernández-Castellano et al.

Table 3: Differences between SCC and LDH regressions by pathogen (p-value). ${ }^{\dagger}$ No pathogen isolated. ${ }^{\ddagger}$ Not statistically tested ${ }^{\S}$ CNS: Coagulase-negative Staphylococcus.

\begin{tabular}{l|l|l|l|l|l|l} 
& Control & E. coli & C. bovis & CNS & S. aureus & S. uberis \\
\hline Control $^{\dagger}$ & & & & & \\
\hline E. coli $^{\ddagger}$ & 0.3212 & & & & \\
\hline C. bovis & 0.4244 & 0.1812 & & & \\
\hline CNS $^{\S}$ & 0.0256 & 0.9586 & 0.0142 & & \\
\hline S. aureus & 0.7938 & 0.9143 & 0.7416 & 0.9071 & \\
\hline S. uberis & 0.1193 & 0.6933 & 0.0516 & 0.3748 & 0.8658 & \\
\hline
\end{tabular}

Table 4: Differences between SCC and IgG regressions by pathogen (p-value). ${ }^{\dagger}$ No pathogen isolated. ${ }^{\ddagger}$ Not statistically tested ${ }^{\S}$ CNS: Coagulase-negative Staphylococcus.

\begin{tabular}{l|l|l|l|l|l|l} 
& Control & E. coli & C. bovis & CNS & S. aureus & S. uberis \\
\hline Control $^{\dagger}$ & & & & & \\
\hline E. coli & & & & & \\
\hline C. bovis & 0.4145 & 0.4365 & 0.5053 & & & \\
\hline CNS $^{\S}$ & 0.8268 & 0.4319 & 0.1710 & & \\
\hline S. aureus & 0.8645 & 0.4259 & 0.1235 & 0.8860 & & \\
\hline S. uberis & 0.7565 & 0.4457 & 0.3675 & 0.8242 & 0.7377 & \\
\hline
\end{tabular}

Table 5: Differences between IgG and LDH regression by pathogen (p-value). ${ }^{\dagger}$ No pathogen isolated. ${ }^{\ddagger}$ Not statistically tested ${ }^{\S}$ CNS: Coagulase-negative Staphylococcus.

\begin{tabular}{l|l|l|l|l|l|l} 
& Control & E. coli & C. bovis & CNS & S. aureus & S. uberis \\
\hline Control $^{\dagger}$ & & & & & \\
\hline E. coli $^{\ddagger}$ & 0.1198 & & & & \\
\hline C. bovis & 0.0803 & 0.0590 & & & \\
\hline CNS $^{\S}$ & 0.5113 & 0.1067 & 0.1294 & & \\
\hline S. aureus & 0.8650 & 0.6486 & 0.7436 & 0.8460 & \\
\hline S. uberis & 0.2391 & 0.0979 & 0.1849 & 0.5571 & 0.8321 & \\
\hline
\end{tabular}


Milk somatic cell count, lactate dehydrogenase activity, and immunoglobulin $\mathrm{G}$ concentration associated with mastitis caused by different pathogens: A field study

L.E. Hernández-Castellano et al. was found. These results were similar to those described by Hiss et al. (2007) who described lower LDH activity in control quarters compared to those infected by Streptococcus spp. The fact that LDH activity in milk samples with $C$. bovis isolation did not differ from those from control quarters was expected as this bacteria is not highly pathogenic (Hiss et al., 2007). Besides the low number of samples found from quarters infected with E. coli, it seems that this bacteria also causes high LDH activity (2.50 $\log 10 \mathrm{U} / \mathrm{L})$ similar to quarters infected with S. uberis. According to Wellnitz et al. (2013) the intramammary infusion of lipopolysaccharide (LPS), the main pathogenic component of gram-negative bacteria such as E. coli, caused higher LDH activity than the infusion of lipoteichoic acid (LTA), the main pathogenic component of gram-positive bacteria such as $S$. aureus. According to this study, the high pathogenicity of E. coli could increase tissue damage and the attraction of immune cells (mainly granulocytes and lymphocytes), therefore increasing the LDH. However, it seems that $S$. uberis (gram-positive bacteria) and E. coli (gram-negative bacteria) caused similar LDH activity in infected quarters.

Immunoglobulins (mainly $\operatorname{Ig} G$ ), as part of the specific immune response, play an important role during mastitis. Despite this fact, few studies have been performed to examine how IgG, transferred from blood to milk during mastitis, is affected by different pathogens. In the present study, IgG concentration only differed from the control group in samples where $S$. uberis was isolated $(0.79 \mathrm{mg} / \mathrm{mL})$. Although not statistically significant, it appears that $E$. coli caused a much higher IgG concentration $(1.35 \mathrm{mg} / \mathrm{mL})$ than any gram-positive bacteria identified in this study. As described by Wellnitz et al. (2013), the immune response during mastitis induced by LPS from E. coli opens the blood-milk barrier to a greater extent than LTA from $S$. aureus, allowing higher transfer not only of LDH but also of IgG.

In this study, all experimental variables were positively correlated, although LDH activity and SCC were the highest correlated variables. In agreement with these results, several authors have described a positive correlation between LDH activity and SCC (Klinkon et al., 2002; Hiss et al., 2007). Additionally, in the present study, the correlation between LDH activity and SCC changed when milk samples were classified by bacteria. Differences in regression slopes were detected, although since data only from gram positive bacteria was included in the statistical analysis, these differences were not strongly evident. In quarter milk samples from which CNS were isolated, the LDH activity/SCC regression slope differed from the quarter milk samples with C. bovis isolation or control samples. Additionally, differences between LDH activity/SCC regression slopes from milk samples with $S$. uberis and $C$. bovis were de- tected. In this study, the differences in LDH activity/ SCC correlations and regression slopes among different gram-positive bacteria may occur due to similar activation of the innate immune system (indicated by SCC), but differential activation of the adaptive immune system (represented by LDH activity). When samples were grouped by bacteria, SCC/IgG and LDH/IgG correlations changed, although these correlations were lower compared to LDH/SCC.

No differences between SCC/IgG regression slopes were detected. Despite the lack of described correlations or regressions between SCC and IgG in the literature, Wellnitz et al. (2013) observed a parallel increase of SCC and $\operatorname{IgG}\left(\operatorname{IgG}_{2}\right)$ in milk 2 hours after LPS challenge. However, the study did not detect a similar parallel increase of $\operatorname{IgG}\left(\operatorname{IgG}_{2}\right)$ after LTA challenge, although $\operatorname{IgG}_{2}$ concentration in the LTA group was higher than in control group. According to these findings, it appears that gram-positive bacteria (frequently causing subclinical mastitis) do not disrupt the blood milk barrier to the extent of gram-negative bacteria, which obviously affects the transfer of IgG. Furthermore, as intramammary infections caused by E. coli induce the efficient transfer of IgG from blood to milk (Wellnitz et al., 2013), it is thought that the SCC/IgG regression would differ from those observed from gram-positive bacteria. Nevertheless and as a consequence of the low number of E. coli cases detected in this study, this statement could not be tested.

LDH and IgG were positively correlated. However, when IgG concentration and LDH activity were classified by the isolated udder pathogen, only those groups of milk samples with isolation of $C$. bovis, coagulase-negative Staphylococcus, S. uberis and S. aureus were correlated. According to these results, it seems that the different gram-positive bacteria detected in this study caused similar adaptive immune system reaction, as no differences between LDH/IgG regression slopes were found.

In case of gram-negative bacteria, Lehmann et al. (2013) and Wellnitz et al. (2015) using LPS to experimentally simulate mastitis caused by E. coli, found that after LPS-challenge both LDH and $\operatorname{IgG}\left(\operatorname{IgG}_{1}\right.$ and $\left.\operatorname{IgG}_{2}\right)$ increased. As described before, the current study focused on changes in SCC, LDH activity and IgG concentration in spontaneous mastitis cases on commercial dairy farms whereas previous experimental studies used LPS and LTA to experimentally induced mastitis. Due to this fact, only 3 mastitis cases caused by E. coli were detected. Despite the lack of statistical analysis on this bacteria group and taking into consideration the two studies cited above, it seems that the $\mathrm{LDH} / \mathrm{IgG}$ regression slope observed in this type of mastitis differed dramatically from the ones caused by gram-negative bacteria. 


\section{Conclusion}

In conclusion, the observed positive correlation between the 3 variables studied indicates that they all increase during mastitis. However, the correlations among these variables depend on the mastitis causing pathogen. Although not statistically evaluated due to the low number of cases, it seems that gram-negative bacteria, such as E. coli, cause a much higher IgG concentration and LDH activity compared to the gram-positive bacteria identified in this study (with the exception of S. uberis). Thus, the suitability of LDH as a marker for IgG transfer is also dependent on the pathogen. $\mathrm{LDH}$ in combination with SCC may be used as a marker to differentiate between gram-positive and gram-negative bacteria but does not allow differentiating the immune response among different gram-positive bacteria.
Milk somatic cell count, lactate dehydrogenase activity, and immunoglobulin $\mathrm{G}$ concentration associated with mastitis caused by different pathogens: A field study

L.E. Hernández-Castellano et al.

\section{Nombre de cellules somatiques, lactate déshydrogénase et immuno- globulines $\mathrm{G}$ dans le lait lors de mam- mites causées par divers pathogènes: une étude de terrain}

Dans le présent travail, on a étudié les liens entre le nombre de cellules somatiques (somatic cell count, SCC), les immunoglobulines G (IgG) et la lactate déshydrogénase en fonction des pathogènes à l'origine de la mammite. On a prélevé des échantillons de lait provenant de 152 quartiers dans deux exploitations suisses équipées d'un robot de traite. Outre la mesure du SCC, des IgG et de la LDH, on a effectué un examen bactériologique des échantillons. Après classement selon les types de pathogènes (contrôle, S. aureus, C. bovis, Straphylocoques coagulase négatifs, $S$. uberis), on a calculé les corrélations et régressions entre SCC, LDH et IgG. Tous les pathogènes de mammite trouvés étaient des bactéries Gram positif; seuls trois quartiers étaient infectés par E. coli. Tant le SCC que la LDH étaient différents selon le type de pathogène mais les IgG n'étaient élevées par rapport aux contrôles que dans les quartiers dans lesquels on a mis en évidence S.uberis. Toutes les variables examinées étaient corrélées positivement entre elles. En ce qui concerne les contrôles, S. aureus, C. bovis et les Straphylocoques coagulase négatifs, la corrélation entre SCC et LDH était particulièrement élevée. Ce n'est que dans le groupe des $S$. uberis que la corrélation entre LDH et IgG était plus élevée qu'entre SCC et LDH. Les coefficients de régression entre SCC et LDH étaient différents selon les types de pathogènes, alors que la régression entre SCC et IgG de même qu'entre LDH et IgG ne présentait pas de différence suivant les groupes. $\mathrm{Vu}$ leur petit nombre $(n=3)$, les quartiers infectés par $E$. coli n'ont pas pu être pris en compte dans l'exploitation statistique. On constate toutefois que, dans tous les quartiers infectés par E. coli, on mesure des valeurs nettement plus élevées d'IgG et de LDH que dans ceux infectés par des bactéries Gram positif. Cette étude montre que l'utilisabilité de la LDH comme marqueur du transfert des $\mathrm{IgG}$ du sang au lait dépend du type de pathogène. La relation entre SCC et LDH pourrait servir de marqueur

\section{Numero delle cellule somatiche, latta- to deidrogenasi e immunoglobulina $G$ nel latte di animali affetti da mastite causata da vari agenti patogeni: uno studio}

Nel corso di questo studio si sono studiate le relazioni tra il numero delle cellule somatiche (SCC), le immunoglobuline $\mathrm{G}(\mathrm{IgG})$ e il lattato deidrogenasi (LDH) in funzione del patogeno che causa le mastiti. I campioni di latte provenienti da 152 quarti di mammella sono stati raccolti in due stabilimenti svizzeri di mungitura automatizzata. In aggiunta alla determinazione delle SCC, IgG e LDH, i campioni sono stati esaminati batteriologicamente. Dopo la divisione in tipi di patogeni (controlli, S. aureus, C. bovis, stafilococchi coagulasi-negativi, S. uberis) sono state calcolate le correlazioni e le regressioni tra SCC, LDH e IgG. Tutti gli agenti patogeni della mastite trovati, erano batteri gram-positivi; purtroppo i $3 / 4$ erano infettati da E. coli. Entrambi SCC e LDH differivano tra i tipi di agenti patogeni. Nei quarti in cui è stato rilevato $S$. uberis, le IgG erano maggiori rispetto ai controlli. Tutte le variabili studiate sono state correlate l'una con l'altra in modo positivo. Per i controlli, gli $S$. aureus, i C. bovis e gli stafilococchi coagulasi-negativi i valori di SCC e LDH erano maggiormente correlati. Solo nel gruppo S. uberis la correlazione tra LDH e IgG era maggiore di quella tra SCC e LDH. I coefficienti di regressione tra SCC e LDH differivano tra i tipi di patogeni, mentre le regressioni tra SCC e IgG e tra LDH e IgG non hanno mostrato differenze tra i gruppi. A causa del loro scarso numero $(n=3)$, i quarti infettati da E. coli non potevano essere inclusi nell'analisi statistica. Bisogna sottolineare che tutti i valori per le IgG e il LDH dei quarti infettati da E. coli erano molto più elevati di tutti i quarti infettati da gram-positivi. Questo studio dimostra che l'utilità di LDH come marcatore per il trasferimento delle $\operatorname{IgG}$ dal sangue al latte è patogeno-dipendente. Il rapporto tra SCC e LDH potrebbe servire come marcatore per la differenziazione delle infezioni gram-positive e gram-negative ma non è utile per distinguere tra diversi batteri gram-positivi. 
Milk somatic cell count, lactate dehydrogenase activity, and immunoglobulin $\mathrm{G}$ concentration associated with mastitis caused by different path-

ogens: A field study

L.E. Hernández-Castellano

et al. pour la différenciation entre les infections à Gram positifs ou négatifs; par contre il ne semble pas possible de l'utiliser pour faire une différence entre les diverses bactéries à Gram positifs.

\section{References}

Anonymous: Laboratory handbook on bovine mastitis. 1999, National Mastitis Council, Verona, WI.

Chagunda M. G., Larsen T., Bjerring M., Ingvartsen K. L. L-lactate dehydrogenase and $\mathrm{N}$-acetyl-beta-D-glucosaminidase activities in bovine milk as indicators of non-specific mastitis. J. Dairy Res. 2006, 73: 431-440.

Halasa, T., Huijps K., Osteras O., Hogeveen H.: Economic effects of bovine mastitis and mastitis management: a review. The Veterinary quarterly 2007, 29: 18-31.

Hiss S., Mueller U., Neu-Zahren A., Sauerwein H.: Haptoglobin and lactate dehydrogenase measurements in milk for the identification of subclinically diseased udder quarters. Vet. Med-Czech. 2007, 52: 245-252.

Hogan J. S., Gonzalez R. N., Harmon R. J., Nickerson S. C., Oliver S. P., Pankey J. W., Smith K. L.: Laboratory Handbook on Bovine Mastitis. 1999, National Mastitis Council, Madison.

Klinkon, M., Klopcic M., Osterc J.: Potential use of milk analysis for udder health control in highly productive dairy herd. Acta Agrar. Kaposváriensis 2002, 6: 177-185.

Lehmann M., Wall S. K., Wellnitz O., Bruckmaier R. M.: Changes in milk L-lactate, lactate dehydrogenase, serum albumin, and IgG during milk ejection and their association with somatic cell count. J. Dairy Res. 2015, 82: 129-134.

Lehmann M., Wellnitz O., Bruckmaier R. M.: Concomitant lipopolysaccharide-induced transfer of blood-derived components including immunoglobulins into milk. J. Dairy Sci. 2013, 96: 889-896.

Milner P., Page K. L., Hillerton J. E.: The effects of early antibiotic treatment following diagnosis of mastitis detected by a change in the electrical conductivity of milk. J. Dairy Sci. 1997, 80: 859-863.

Nyman A. K., Persson Waller K., Bennedsgaard T. W., Larsen $T$., Emanuelson U.: Associations of udder-health indicators with cow factors and with intramammary infection in dairy cows. J. Dairy Sci. 2014, 97: 5459-5473.

Wall, S. K., Hernández-Castellano, L. E., Ahmadpour, A., Bruckmaier, R. M., Wellnitz, O.: Differential glucocorticoid-induced closure of the blood-milk barrier during lipopolysaccharide- and lipoteichoic acid-induced mastitis in dairy cows. J. Dairy Sci. 2016, 99: 7544-7553.

Wellnitz, O., Arnold E. T., Bruckmaier R. M.: Lipopolysaccharide and lipoteichoic acid induce different immune responses in the bovine mammary gland. J. Dairy Sci. 2011 94: 5405-5412.

Wellnitz, O., Arnold E. T., Lehmann M., Bruckmaier R. M.: Short communication: differential immunoglobulin transfer during mastitis challenge by pathogen-specific components. J. Dairy Sci. 2013, 96: 1681-1684.
Wellnitz O., Zbinden C., Lüttgenau J., Bollwein H., Bruckmaier R. M.: Different chronological patterns of appearance of blood derived milk components during mastitis indicate different mechanisms of transfer from blood into milk. J. Dairy Res. 2015, 82: 322-327.

\section{Corresponding author}

Rupert M. Bruckmaier Veterinary Physiology

Bremgartenstr. 109a

$\mathrm{CH}-3012$ Bern

Tel: +41-31-6312324

Fax: +41-31-6312640

E-Mail: rupert.bruckmaier@vetsuisse.unibe.ch 